\title{
Praxis and Doxa: What a focus on ritual can offer evolutionary explanations of religion
}

\author{
Eleanor A. Power \\ Santa Fe Institute
}

Sterelny's emphasis on praxis (practice, ritual) rather than doxa (belief) is an important pushback against overly mentalized explanations of the evolution of religion. By focusing on the issue of timing (why did religion emerge when it did, and not sooner or later?), Sterelny finds himself concentrating on changes in human sociality, not in the human mind. Clearly, both belief and practice are crucial elements of religion, as many recent attempts at synthesizing the field make clear (e.g., Purzycki et al 2009, Atran and Henrich 2010, Norenzayan et al 2016). Sterelny makes a convincing case for the particular importance of ritual to the origin of religion, though, and it will be rich fodder for further discussion in the field. Here, I comment on what I see as the benefits that this renewed focus on praxis (to accompany the rich body of work on doxa) can hold for the evolutionary study of religion.

First, an emphasis on religious practice may help to correct for a still lingering conception of religion writ large as something like an Abrahamic faith, if not more specifically a Protestant faith (cf. Henrich et al 2010, Graham and Haidt 2010, Norenzayan 2016). This presumption can lead to important oversights in the literature. For example, most of the studies using religious primes to investigate the relationship between religiosity and prosociality look at the effect of abstract religious concepts and belief propositions, rather than the effect of concrete religious contexts and behaviors. It is telling that in Shariff et al's (2016) recent meta-analysis of priming studies, the studies that had the largest effect on prosociality were those with contextual primes. Similarly, field-based studies had the largest effect while the extreme artificiality of MTurk studies the smallest (Shariff et al 2016). I would suggest that it is not simply the greater realism of these studies that accounts for their larger effect sizes, but also something about the holistic experience that they evoke. Importantly, studies using contextual primes also were fewest in number: only eight of the 92 studies (9\%) used such primes. The relative inattention paid to praxis in this body of work may be due at least in part to a presumption that all religions follow Protestantism in giving primacy of place to faith. More contextual studies and more work on religious practice will help correct this myopia.

Second, I see Sterelny's focus on ritual as an opportunity to bring back into discussion some of the classic works on religion, many of which are surprisingly absent from his manuscript. Sterelny's describes religion as a "mechanism of internal affiliation and identity" (35). This bears a remarkable resemblance to the foundational account of religion put forth by Durkheim, who spoke of how the "collective effervescence" of ritual allows individuals to form into a social group and 
"reaffirm in common their common sentiments" (Durkheim 1995:429). And, it is reminiscent of Turner's (1969) "communitas," the state of communion between undifferentiated individuals that ultimately both affirms the togetherness of individuals and renews the social order (and divisions therein). Despite these commonalities, Sterelny cites neither of these seminal accounts of religion, nor Rappaport's assertion that ritual is an element that is crucial and necessary "to allow human sociability to have developed and be maintained" (Rappaport 1999:15). This oversight is likely a consequence of word limits and a desire to cite more current work, but there are many precursors of Sterelny's "re-explanation" of religion in earlier works. Sterelny provides us an opportunity to revisit some of the canonical works and crucial insights of the anthropology of religion. It is not merely recent ethnographers who have stressed the importance of ritual practice, but all of sociology and anthropology since their founding. It is worth consulting this rich literature (and likely worth renaming Sterelny's "ethnographic model of the evolution of religion" to something with a bit more precision and clarity).

What these foundational studies suggest is that the salience of belief is driven by practice. The willingness to adhere to the tenets of a religion is built on the active practice of that religion (cf. Sosis 2003) and the evidence one sees in the course of that practice that others too are striving to adhere to it (cf. Henrich 2009). In my own fieldwork in South India (Power 2015), I see ample evidence of these reinforcements. When describing one of his first acts of devotion for a Hindu goddess (rolling prostrated around her temple), one man told me:

I came to know the divine and its nature on that day only. I saw a change within my body. I felt some energy inside, an energy that could not be defined. ... Only after doing that I came to know pakti [ardent love for the divine]. I found a change, a divine power. That is to say, I believed in God.

Praxis and doxa are intertwined, and both become stronger in tandem. It is rare that they can ever be fully separated. In a telling parallel to the priming studies mentioned above, experimental studies investigating whether elements of ritual (singing, synchronous movement, pain) can foster cohesion have suggested that the physical experience alone may not be enough (e.g., Reddish et al 2013, Cohen et al 2014). It is when action is undertaken with a sense of commitment and purpose that it may be most potent. Studying either religious belief or practice in isolation is to risk misunderstanding both. As Sterelny argues, both are crucial to religion's development and persistence. Clearer theory and empirics on the feedbacks between religious ritual, belief, and sociality is called for (cf. Whitehouse and Lanman 2014). Such work will not only bring clarity to the origins of religion, but also to its continued salience today.

\section{Bibliography}

Atran, S., \& Henrich, J. (2010). The evolution of religion: how cognitive by-products, adaptive learning heuristics, ritual displays, and group competition generate deep commitments to prosocial religions. Biological Theory, 5(1), 18-30. 
Cohen, E., Mundry, R., \& Kirschner, S. (2014). Religion, synchrony, and cooperation. Religion, Brain \& Behavior, 4(1), 20-30.

Durkheim, E. (1995). The elementary forms of religious life. (K. E. Fields, Trans.). New York: Free Press.

Graham, J., \& Haidt, J. (2010). Beyond beliefs: religions bind individuals into moral communities. Personality and Social Psychology Review, 14(1), 140-150.

Henrich, J. (2009). The evolution of costly displays, cooperation and religion: credibility enhancing displays and their implications for cultural evolution. Evolution and Human Behavior, 30(4), 244-260.

Henrich, J., Heine, S. J., \& Norenzayan, A. (2010). The weirdest people in the world? Behavioral and Brain Sciences, 33(2-3), 61-83.

Norenzayan, A. (2016). Theodiversity. Annual Review of Psychology, 67(1), 465-488.

Norenzayan, A., Shariff, A. F., Gervais, W. M., Willard, A. K., McNamara, R. A., Slingerland, E., \& Henrich, J. (2016). The cultural evolution of prosocial religions. Behavioral and Brain Sciences, 39, e1.

Power, E. A. (2015). Building bigness: Religious practice and social support in rural South India (Doctoral Dissertation). Stanford University, Stanford, CA.

Purzycki, B. G., \& Sosis, R. (2009). The religious system as adaptive: cognitive flexibility, public displays, and acceptance. In E. Voland \& W. Schiefenhövel (Eds.), The Biological Evolution of Religious Mind and Behaviour (pp. 243-256). Berlin, Heidelberg: Springer.

Rappaport, R. A. (1999). Ritual and religion in the making of humanity. Cambridge, UK; New York: Cambridge University Press.

Reddish, P., Fischer, R., \& Bulbulia, J. (2013). Let's dance together: synchrony, shared intentionality and cooperation. PLOS ONE, 8(8), e71182.

Shariff, A. F., Willard, A. K., Andersen, T., \& Norenzayan, A. (2016). Religious priming a meta-analysis with a focus on prosociality. Personality and Social Psychology Review, 20(1), 27-48.

Sosis, R. (2003). Why aren't we all Hutterites?: Costly signaling theory and religious behavior. Human Nature, 14(2), 91-127.

Turner, V. W. (1969). The ritual process: structure and anti-structure. Chicago, IL: Aldine Publishing Co.

Whitehouse, H., \& Lanman, J. A. (2014). The ties that bind us: ritual, fusion, and identification. Current Anthropology, 55(6), 674-695. 